\title{
Influence of E-Learning in Method of Learning Web Programming
}

\author{
Dedi S Soegotto ${ }^{1}$, Arrizky Hasya Pratama² \\ $\underline{\text { dedissoegoto@email.unikom.ac.id }}{ }^{1}, \underline{\text { arrizkyhasya@mahasiswa.unikom.ac.id }}^{2}$ \} \\ Departemen Manajemen, Universitas Komputer Indonesia, Indonesia ${ }^{1}$, Fakultas Teknik dan Ilmu \\ Komputer, Universitas Komputer Indonesia, Indonesia ${ }^{2}$
}

\begin{abstract}
This research aims to help people in business in using e-commerce and increase the sales results in the marketing of a fabric industry in Bandung. So far, marketing system has been carried out in a manual system that is handled directly by the customer which makes it time-consuming and costly. Along with the usage of E-commerce in various fields, it is also used in the sales of fabrics. Making a website is one of the multiple ways to increase sales. In the current era of globalization, internet usage and social media are mandatory for many merchants who utilize sales through E-Commerce. This study uses a descriptive method with a qualitative approach carried out in specific fabric industry. The results of this study are the increase in sales of the products and how websites can be utilized in industrial areas. This happens because in using E-Commerce, customers can ignore distance and time. whenever and wherever the customer no longer has to visit or buy the items directly to the store. The conclusion is that e-commerce systems make it easy for users to access information about fabric products online.
\end{abstract}

Keywords: e-commerce, marketing, industry 


\section{Introduction}

Learning to develop computer programs is known to be difficult for many beginners. For decades, researchers have built an automated e-learning system to minimize obstacles in learning programming [1]. In this internet era, websites that provide online-based learning or Elearning are many. It is very easy for us to look for online classes or materials that we want to study, one of them is Web Programming Languages such as PHP, Javascript, Html, CSS.

Web programming is a skill that requires practice. To strengthen programming skills, you need much practice. So, practical activity plays an important role in the learning process [2]. Internet Utilization is a small business trend in the era of globalization that is being used today which has easier access to the internet, increasing number of providers, greater bandwidth and affordable internet costs [3]. An example of the form of technological progress in the world of education is the concept of e-learning or distance learning. Some experts even predict that learning models that exist today, probably will not be found again in the future[4]. Online education is a part of long-distance education and can also be referred to as online learning, elearning, or web-based learning [5]. E-learning refers to the use of information and communication technology to allow access to online learning or teaching resources [6]. Based on research conducted by Gottfried Vossen, and Peter Westerkamp Learners vary significantly in their prerequisites, their abilities, their goals to approach the learning system, the speed of their learning, the way they learn, and the time (and money) they can spend while learning [7].

A sophisticated web-based system has been developed to provide an effective projectbased educational environment in learning activities for "web designing and programming" which of course can be done easily [8]. According to Rita Kop, people who study in informal networks will choose the subject they wanted to learn or the activity they wanted to do, but in an interconnected environment, they have to make other choices too. For example, they have to manage time, set their own learning goals, find resources, and try new tools and make them function which generally called Self Directing Learning [9]. But according to the research conducted by Brian Dorn and Mark Guzdial The number of web content can be a double-edged sword because finding the information can be time-consuming. [10].

The purpose of this research is to find out how E-Learning influences learning methods of web programming, by using descriptive methods by using observation data collection techniques, case studies and using previous research related to E-learning Web Programming.

\section{Material and Methods}

The research method used is a descriptive method to get an accurate picture using quantitative data, the techniques used are observation and case studies. In this case, this study takes the example of an Indonesian language e-learning website namely sekolahkoding.com

\section{Result and Discussion}

There are so many websites that provide material or classes about creating websites using Bahasa Indonesia, for example, Sekolahkoding.com which provides free classes and paid 
classes. Of course there is a difference between free classes and paid classes, where paid classes can access all materials, but free classes can only access part of the full material. Sekolahkoding.com itself is a site for learning programming, especially web programming (website) created by Hilman Ramadhan, sekolahkoding.com was made because several years ago it was difficult to find quality web-programming video tutorials in Bahasa Indonesia (Figure 1).

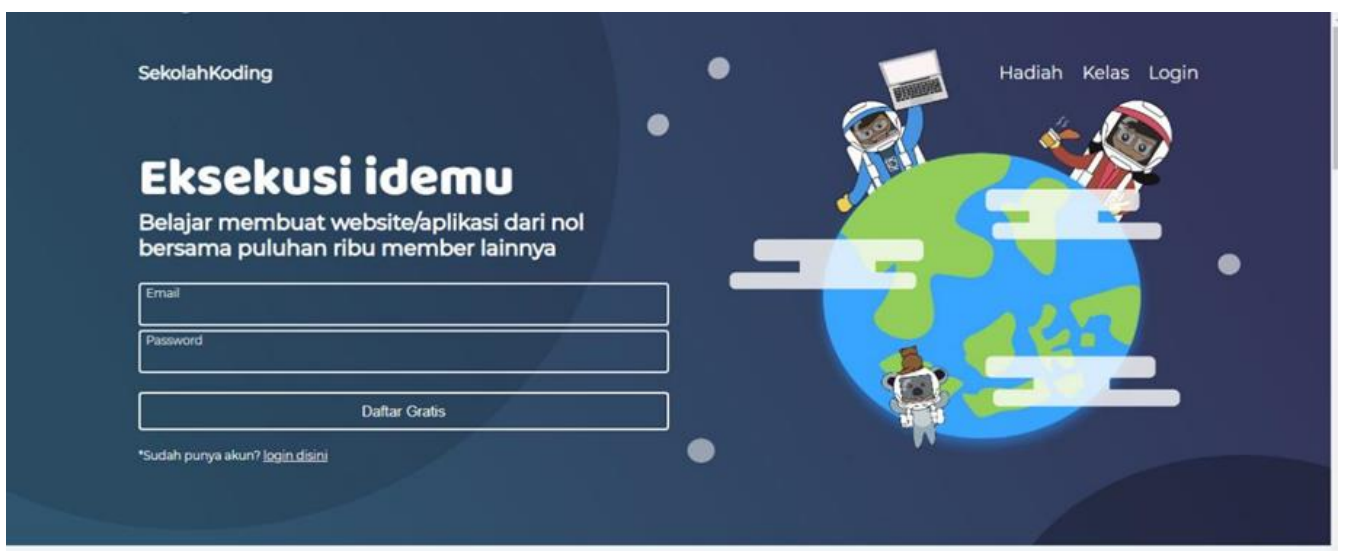

Fig. 1. Main page sekolahkoding.com. This figure was adopted from 10 December 2018.

There are many advantages gained when learning web programming using e-learning methods such as:

- $\quad$ The number of modules available.

- $\quad$ The students can study anywhere and anytime.

- $\quad$ There is a Forum to post questions or discuss with other members

- $\quad$ Can publish works and get feedback

- $\quad$ The module is always up to date

- $\quad$ Requires a relatively low cost

In the class view, we can search for what material we are going to study, and there is a tag filter according to the programming language to provide easier searching (Figure 2). 


\begin{tabular}{|c|c|c|}
\hline Mau belajar apa? & Cari & Filter Tag \\
\hline nextis coacts & \multicolumn{2}{|l|}{ reactis } \\
\hline Nextjs Framework react lebih powerful & \multicolumn{2}{|c|}{ React komponen Lebih dalam } \\
\hline $\begin{array}{l}\text { Kamu sudah bermain dengan reactjs tapi } \\
\text { merasa ada yang kurang? mungkin kamu ingin } \\
\text { membuat aplikasi r... }\end{array}$ & \multicolumn{2}{|c|}{$\begin{array}{l}\text { Kamu sudah belajar dasar dari ReactJS? kita } \\
\text { mulai mengenal konsep konsep } \\
\text { intermediatenya untuk belaj... }\end{array}$} \\
\hline () 1 minggu yang lalu & (D) 7 video & () 2 minggu yang lalu \\
\hline django & \multicolumn{2}{|l|}{ django } \\
\hline Aplikasi forum dengan Django & \multicolumn{2}{|c|}{ Class Based View Django } \\
\hline $\begin{array}{l}\text { Kita akan membuat aplikasi forum lengkap } \\
\text { dengan sistem authentikasi dan komentar } \\
\text { menggunakan class b... }\end{array}$ & \multicolumn{2}{|c|}{$\begin{array}{l}\text { Selain menggunakan function based untuk } \\
\text { viewnya, django juga menyediakan -Class Based } \\
\text { View-agar str... }\end{array}$} \\
\hline () 2 bulan yang lalu & (D) 5 video & () 2 bulan yang lalu \\
\hline
\end{tabular}

Fig. 2. Class page sekolahkoding.com. This figure was adopted from 10 December 2018.

Lots of class material are available, just by logging in user can access the modules (Figure 3).

kenalan dengan flask
web app pertama dengan flask
restart server automatis dan set windows
routing flask statis dan dinamis
akses form metode post
akses parameter get
logika pada html jinja

Fig. 3. Display of class material sekolahkoding.com. This figure was adopted from 10 December 2018.

Some material can only be opened with paid features marked with a padlock symbol (Figure 4). 


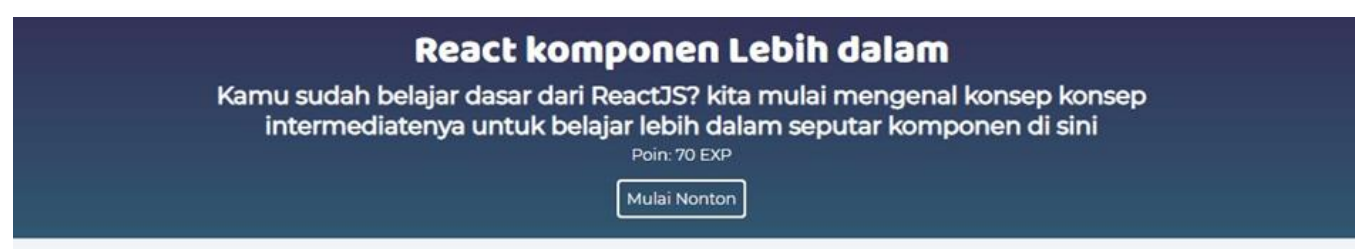

Composition children prop dan konten fleksibel
Mengenal react context
contexttype di context api
basic HOC higher order component

Fig. 4. Display of paid class material sekolahkoding.com. This figure was adopted from 10 December 2018.

After clicking on the selected material, the content will appear in the form of a step-by-step video. In addition, there is a Save PR button to watch the video later and the material content page is saved to the profile considering if we want to continue the material later (Figure 5).

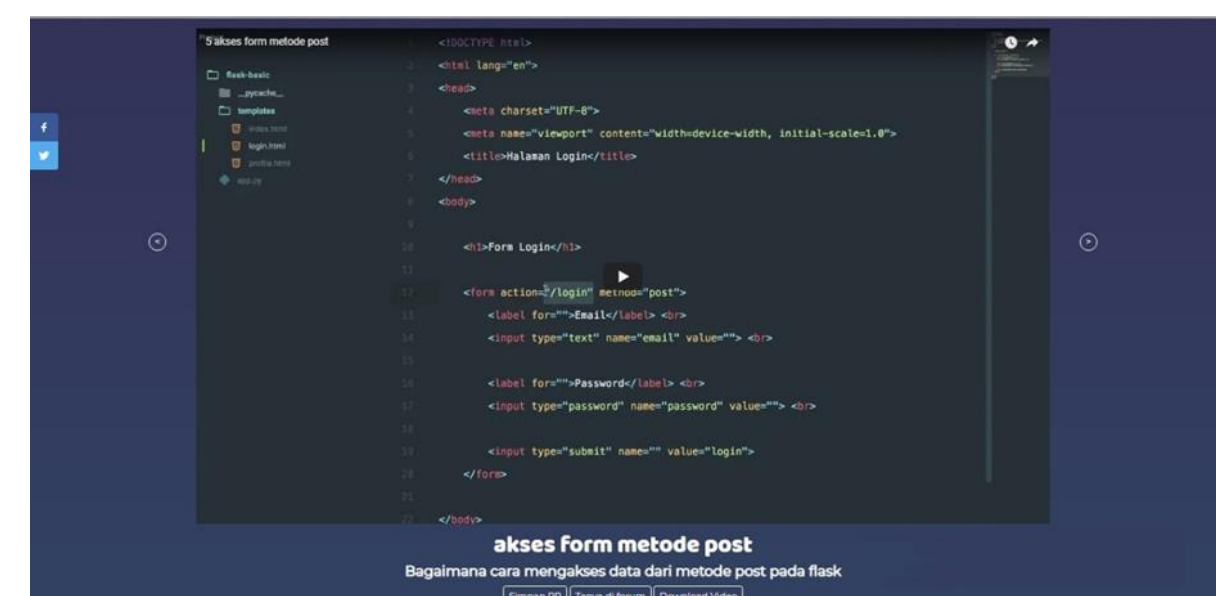

Fig. 5. Content page sekolahkoding.com. This figure was adopted on 10 December 2018.

For users who do not know where to start, the web has prepared a page called Learning Travel which starts from the basic HTML front end (Figure 6). 

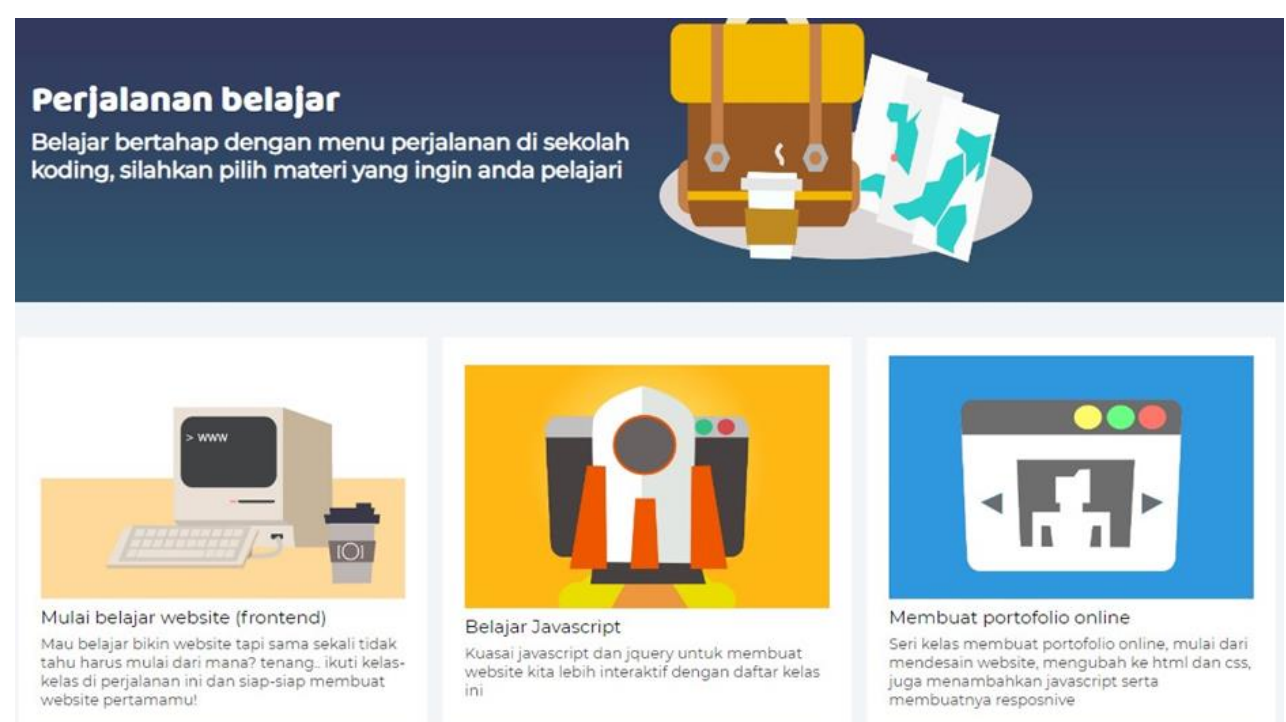

Fig. 6. Learning Travel Page sekolahkoding.com. This figure was adopted from 10 December 2018.

There is a Forum Page so that users can get the information they need and can also ask if they find difficulties in learning web programming, there is also a search topic feature (Figure 7).

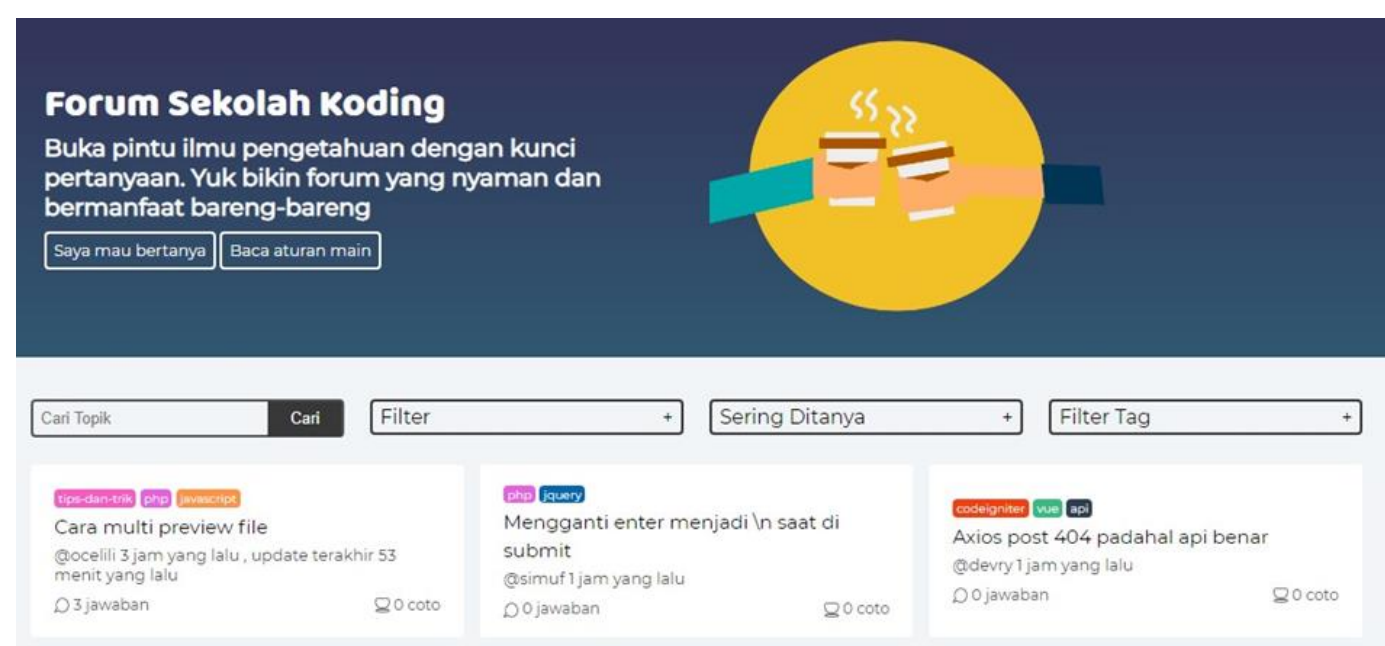

Fig. 7. Forum Page sekolahkoding.com. This figure was adopted from 10 December 2018.

Based on the example case of schoolcoding.com above, it is very beneficial for prospective programmers to learn Web Programming. 


\section{Conclusion}

The usage of the Internet at this time provides many benefits, one of them is the E-Learning that makes it easier to find material and learning modules, Also, the existence of a Website to learn web programming can be used as a place for prospective programmers to develop their programming skills.

\section{References}

[1] Law, K. M., \& Lee, V. C.: YT Yu. Learning motivation in elearning facilitated computer programming courses. Computers and Education, 55(1), 218-228 (2010)

[2] Elgamal, A. F., Abas, H. A., \& Baladoh, E. S.: An interactive e-learning system for improving web programming skills. Education and Information Technologies, 18(1), 29$46(2013)$

[3] E. S. Soegoto.: "Enterpreneurship", in Enterpreneurship Menjadi Pebisnis Ulung, 1st Ed, Jakarta : PT. Elex Media Komputindo (2009)

[4] Praharsi, Y.: Penggunaan Model e-Media Berbasis Komputer dalam Pembangunan Sistem e-Learning (Studi Kasus: e-Media untuk Pembelajaran Gerak Osilasi). In Seminar Nasional Aplikasi Teknologi Informasi (SNATI) (2004)

[5] Finch, D., \& Jacobs, K.: Online education: Best practices to promote learning. In Proceedings of the human factors and ergonomics society annual meeting (Vol. 56, No. 1, pp. 546-550). Sage CA: Los Angeles, CA: SAGE Publications (2012)

[6] V Arkorful \& N Abaidoo.: The role of e-learning, the advantages and disadvantages of its adoption in Higher Education. P-3 ref2 (2014)

[7] Vossen, G., \& Westerkamp, P.: E-learning as a Web service. In Database Engineering and Applications Symposium, 2003. Proceedings. Seventh International (pp. 242-249). IEEE (2003)

[8] Utku Köse.: A web based system for project-based learning activities in "web design and programming" course (2010)

[9] Kop, R.: The challenges to connectivist learning on open online networks: Learning experiences during a massive open online course. The International Review of Research in Open and Distributed Learning, 12(3), 19-38 (2011)

[10] Dorn, B., \& Guzdial, M.: Learning on the job: characterizing the programming knowledge and learning strategies of web designers. In Proceedings of the SIGCHI Conference on Human Factors in Computing Systems (pp. 703-712). ACM (2010) 